\title{
Chapter 7 \\ Changing Structures and the Role of Education in the Development of the Educational System in Czechia
}

\author{
Silvie Rita Kučerová, Kateřina Trnková, and Petr Meyer
}

Since the mid-twentieth century, economically developed countries have witnessed crucial changes in their elementary school systems. Some of these changes were transformed conceptions of educational politics and formulations of educational reforms (e.g., Dvořák, Starý, \& Urbánek, 2015a; Tyack, \& Cuban, 1995); others were altered school spatial patterns. After the nineteenth-century wave of school construction, the late twentieth century brought a reduction in the number of schools and the concentration of educational functions in larger centers further up the urban hierarchy (Ribchester \& Edwards, 1999). Although this general concentration process was inevitable (Hampl, 2000), as it was rooted in organizational principles as well as demographic trends, it gave rise to a discussion of school's role in society and for local communities (Kvalsund, 2009). The school closures that followed were connected with overall development and quality of life in rural and remote areas (Dostál \& Markusse, 1989).

The original version of this chapter was revised: The affiliation of all the authors were corrected. The correction to this chapter is available at https://doi.org/10.1007/978-3-030-18799-6_18

S. R. Kučerová $(\bowtie)$

Department of Geography, Faculty of Science, J. E. Purkyně University in Ústí nad Labem,

Ústí nad Labem, Czechia

e-mail: silvie.kucerova@ujep.cz

K. Trnková

National Institute for Futher Education, Brno, Czechia

Department of Educational Sciences, Faculty of Arts, Masaryk University, Brno, Czechia e-mail: trnkova@nidv.cz

P. Meyer

Department of Social Geography and Regional Development, Faculty of Science,

Charles University, Prague, Czechia

Department of Geography, Faculty of Science, J. E. Purkyně University in Ústí nad Labem,

Ústí nad Labem, Czechia

e-mail: petr.meyer@ujep.cz 
Critical voices first arose in the 1970s, when the largest transformation of the elementary school pattern began-especially in democratic European countries, but also other developed countries across the world-leading to emancipation of small rural schools (e.g., Bell \& Sigsworth, 1987; Kramer, 1993; Lyson, 2002; Solstad, 1997; Witten, McCreanor, Kearns, \& Ramasubramanian, 2001) and their later appreciation as an important elements of educational system with their specific pedagogical and social culture (e.g., Åberg-Bengtsson, 2009; Smit, Hyry-Beihammer, \& Raggl, 2015). Nevertheless, the reforms continued in former countries of the Eastern bloc, changing the elementary school network with consequences that have lasted to the present day (Bajerski, 2015; Kovács, 2012; Kučerová \& Kučera, 2012).

In this chapter, we present the changes undergone by Czechia's system of elementary education. In recent decades, the country of Czechia has transformed itself from a centrally planned economy controlled by the Communist regime towards a democratic society and free market economy. This chapter will explore ways in which, in the course of the twentieth century to the present day, the spatial organization of elementary education in Czechia has been transformed along four dimensions: The first dimension refers to changes in the objective external conditions of education (mainly the evolution of settlement structures, the evolution of the number of persons in need of education, and subsequently the transformation of the management of education across a territory). The second concerns the development of political doctrine and the economic situation and direct connections with the development of both educational and regional policies. The third dimension entails those changes of the concept, forms, and content of education itself that are dealt with pedagogical-psychological theories. The fourth dimension involves how the perception of education's role, recognized competencies, and social relevance has evolved.

An analysis of the spatial distribution of schools as well as a discussion of the consequences of regional and educational policies in Czechia help us answer the following questions: Are changes in the spatial organization of education related to regional education policy as well as to pedagogical concepts? Are territorial and educational organization connected in any way? How is elementary education characteristically provided and utilized in a directive and unfree social system in comparison to a system with a decentralized administration that provides actors with greater autonomy?

\section{Factors Affecting Spatial Distribution and the Organization of Elementary Education}

We are restricting our attention to elementary education, and the conditions of its provision and realization can be specified as follows on the basis of the four aforementioned dimensions.

From the general perspective of its external objective conditions (the first dimension), education's spatial organization is primarily affected by population and settlement characteristics. For one, there exists the spatial distribution of the population 
itself at the macroregional level-which is particularly contingent on altitude, climatic conditions, and historical path dependencies (Åberg-Bengtsson, 2009; Green $\&$ Letts, 2007) —as well as at the meso- and microregional levels — which are especially influenced by orography (e.g., Kučerová, Bláha, \& Kučera, 2015a). Another important factor is constituted by the structural characteristics of a population inhabiting a particular territory (demographic, cultural, and socioeconomic) (Barakat, 2015), settlement structure (Bajerski, 2015), and transport characteristics, that is, the existence and functioning of road networks and means of transport (Kučerová, Mattern, Štych, \& Kučera, 2011). The relationships between an educational system and the above-mentioned factors can be quantified and spatially visualized quite easily, such as by using geographic information systems and maps (Kučerová et al., 2015a; Taylor, 2007; for older publications see e.g., Marsden, 1977).

Capturing those social system factors and mechanisms that fall under the second and third dimensions of conditions of education is rather more complicated. In compliance with the mechanisms emphasized by Giddens's (1984) structuration theory or with the new institutionalist paradigm (Berg, 2007), we can state that education's spatial organization within the second dimension mainly depends on three groups of factors:

The first group encompasses the manner in which the education system is managed, its funding mechanisms, and its regulation methods. The basic challenge in managing that system is to determine the degree of centralization versus decentralization (see Kvalsund, 2009; see also Chap. 6 by Gyuris in this volume). That is, it consists of determining the degree of concentration of state authorities managing and controlling powers, as well as the related degree of financial autonomy. Maroy and van Zanten (2009) or Altrichter, Heinrich, and Soukup-Altrichter (2014) mention a wide range of approaches to regulation and intervention in education. These approaches comprise curriculum control, control of the work of school staff, and competition on the educational quasimarket (see below).

The mechanisms of governance are regulated by legislative frameworks that enable the enforcement of a definite form of organizational structure and equipment of particular schools (e.g., minimum school size) (Meusburger, 1998, 2015; Trnková, 2009). School structures and the norm of the shape of elementary schools constitute the second group of factors. A school's structure depends on its operator (public, private, ecclesiastical, etc.) or on its focus (e.g., schools for students with special needs or, by contrast, selective schools), which conditions their conduct on the educational market as well as their catchment area (Jennings, 2010). The term norm of the shape of an elementary school refers to the dilemma of educational policy: whether to maintain more larger, fully organized schools (regularly situated in cities) or to promote system diversity, that is, to also support small schools (namely the rural ones) (Ribchester \& Edwards, 1999). A large urban school has often been used as the "norm of what schools can be and should be like" (Bell \& Sigsworth, 1987, p. 55), and preferred to rural institutions. In urban society, these problems have been defined more strongly in urban terms and in line with urban perception (cf. Cloke \& Goodwin, 1992). Accordingly, many discussions about small schools in rural and remote areas began in the late 1980s and continue to the present day (e.g., Kramer, 1993; Smit et al., 2015; Solstad, 1997). 
Thirdly, the spatial distribution of schools is influenced by factors on the side of learners, or more precisely by school enrollment terms. Constructors of a school catchment system are thus faced with this last organizational challenge: Who is allowed to make decisions about school enrollment? The students themselves, or rather their parents, schools, or public administrators (Jennings, 2010)? On one side, there is the concept of school catchment districts under which schoolchildren living in a school's hinterland are enrolled on the basis of their place of residence (Bajerski, 2015). On the other side, there is the system of parental school choice that has largely evolved under the influence of liberal economic approaches to education. In conditions close to a free market (Maroy \& van Zanten, 2009), parents choose which school their child will attend according to their own preferences. A number of theoretical concepts explaining school choice mechanisms and strategies subsequently emerged in sociology, psychology, economics, and geography (e.g., Cucchiara \& Horvat, 2014; Holloway \& Pimlott-Wilson, 2012; Noreisch, 2007; Straková \& Simonová, 2015).

In the third dimension of conditions of education, spatial organization of education is affected by pedagogical-didactic principles of how teaching, classes, and forms of knowledge transmission should be organized (Bertrand, 1998). Different demands on educational organization arise when classes that are homogenized according to age cohorts are preferred than when it is admissible to teach more grades together in a heterogeneous class. Similarly, what matters is whether emphasis is put on frontal instruction, research-oriented teaching, or even on individual instruction and other alternative forms of education.

The fourth dimension, involving the goals of education and related social expectations, seems to be decisive for the second and third dimensions of educational conditions. These factors determine the setting of both educational policy and regional development policy, as well as the strategies of how individuals act in a particular territory. Beyond the main educational function, the school system provides a range of other functions for individuals, families, communities, and society as a whole (Lyson, 2002).

Van de Werfhorst (2014), for instance, defines four tasks of education: (1) The "labor market task" is specified as preparing youth for the labor market and ensures economic development. (2) The "optimization task" consists of efficiency in sorting students into tracks according to their talents and interests. (3) The equal opportunity program's goal is to provide quality basic education for all children, regardless of their ethnic or socioeconomic background. (4) The "socialization task" denotes socializing citizens into active civic engagement. Experts' perceptions on the importance and the rate of accomplishing individual tasks have evolved incessantly over time along with social system changes.

The labor market task was the first to appear crucial (Halsey, Lauder, Brown, \& Wells, 1997). Since the nineteenth century, state authorities in developed countries have therefore been systematically constructing a network of institutions ensuring compulsory and uniformly organized school attendance. Liberalism and pragmatic pedagogy grounded in Dewey's (1966) thought subsequently strengthened the optimization task by advocating equal opportunities for everyone so that he or she could attain more benefits through the development of his or her abilities with the aid of educational capital. In contrast, economic nationalism claiming a qualified and 
loyal workforce for the national economy (Halsey et al., 1997) amplified the labor market task. In countries that came under Soviet influence after World War II, this idea, together with a unilaterally, ideologically targeted socialization task, governed their educational system until the fall of the Iron Curtain in 1990 (Zounek, Šimáně, \& Knotová, 2017). Contrarily, a vast majority of democratic countries had been accentuating the equal opportunities task since the 1970s. During that period, diverse societal groups, or territorial communities, became emancipated, and their efforts for equal opportunities and equal access to education flourished. These groups called attention to the injustices of educational concepts and management that favored only certain societal groups, areas, or types of schools (Corbett, 2007). Since the 1980s, emphasis has again been placed on the optimization task: Combined with the application of some market principles to education-such as free parental school choice-this task tends to be rather detrimental to equal opportunity (Holloway \& Pimlott-Wilson, 2012). The new institutionalism (Berg, 2007) and the widening enlargement of the European Union at the beginning of the millennium have reinforced (new transnational) socialization and labor market tasks.

Researchers have developed various possible scenarios for education system development to estimate which of the tasks will be determining for the future. A good example is the 2001 OECD report, which presented six so-called "Schooling for Tomorrow Scenarios." Its authors take into consideration the preservation of the existing status of school as an institution as well as its consolidation involving broadening its functions and forms, and possibly also the extension of market approaches of education providers, or, by contrast, the weakening and decline of educational system in favor of other forms of education.

Just like other components of the social system, educational system is a semicomplex whole (Hampl, 2000) cocreated by many interacting factors. It is almost impossible to capture their full extent. Here, we therefore take Czechia as a case study to merely describe the basic connections of changes concerning spatial organization of elementary education with the transformation of broader social circumstances.

\section{Changes of the Czech Educational System and Policies}

\section{Research Organization and Methodology}

In the present study on changes in the spatial organization of elementary education provision in Czechia, we conducted a quantitative analysis of how the geographical organization of elementary schools has evolved on the national level from the middle of the twentieth century. We mainly chose such a long time span because a large number of elementary schools were closed during this period (Trnková, Knotová, \& Chaloupková, 2010). In the second phase, we have attempted to interpret the key development tendencies of the elementary educational system, taking into account educational and regional developmental policies treated by other authors in secondary sources. 
Our quantitative analysis was limited by the availability of relevant statistical data and by the time required to gather such data. Although the analysis covered a very long time period, only a few statistical publications provide data on the number of schools in basic administrative units, such as municipalities. In general, the data were based on the results of the preceding population censuses and provided information about schools in the whole territory of Czechia at four points in time: 1961, 1976, 1990, and 2004. However, information about the presence of a school in a particular municipality often appeared to be incorrect. Therefore, the information provided in the statistical lexicons and databases had to be compared with the data on the number of schools in larger territorial units or corrected with the use of archival sources.

It is here necessary to point out some important specific features of Czechia's education and settlement system that influence all other characteristics and the development of the country's elementary education. Above all, measured by European standards, the settlement pattern is extremely fragmented (Hampl \& Müller, 1998). Czechia's territory $\left(78,000 \mathrm{~km}^{2}\right)$ includes approximately 15,000 settlements (towns, villages, hamlets) that are governed by 6250 local self-government units (municipalities) (Kučera, 2007). For that reason, municipalities are usually divided into rural and urban pursuant to the size limit of 3000 inhabitants (see e.g., Hampl \& Müller, 1998; Perlín \& Šimčíková, 2008). Also for the purpose of our research we selected this population limit on the basis of Act No. 128/2000, Coll., on Municipalities, according to which only a municipality with more than 3000 inhabitants can become a town or a city. ${ }^{1}$ However, it must be noted that opinions about how to define rural areas diverge widely, and no universal definition exists (see e.g., Halfacree, 1993; Hruška, 2014). Although only 30\% of Czechia's population live in small municipalities with less than 3000 inhabitants, these constitute $90 \%$ of all municipalities in the country. The remaining part of the population is concentrated in urban settlements. If rural space is defined in this manner, a little over 2000 elementary schools operate nowadays (60\% of the total in Czechia) (Kučerová \& Kučera, 2012).

On the basis of the data provided in our statistical sources, we have drawn up a list of almost 5500 settlements in which an elementary school existed during at least one of the four designated time spans. In the next step, we integrated the list into a GIS database of Czech municipalities (the boundaries of the municipalities were defined as of January 1, 2016). Taking into consideration the amount of territorialadministrative changes that occurred during the observed period (consolidation of municipalities and in some cases, especially after 1989, their division into new units—see e.g., Hampl \& Müller, 1998), we used the Statistical Lexicon of Municipalities to verify the location of the listed settlements in appropriate municipalities.

\footnotetext{
${ }^{1}$ Legislators introduced this limit in reaction to the excessive self-identification of municipalities during the 1990s to consolidate a definition of an urban municipality, as some municipalities had retained their town status from the ancient times, although their population comprised only several tens or hundreds of inhabitants.
} 
This process of data collection and organization produced a database that has allowed retrospective historical comparison of the number of elementary schools for all the municipalities in Czechia, according to either the rural or urban status of their municipality in four distinct years: 1961, 1976, 1990, and 2004. The database also included information on school type. Act No. 561/2004 Coll. on Education dictates that elementary school education in Czechia is compulsory for a duration of 9 years. It is provided either by large "complete" elementary schools, which contain all nine grade levels, or by smaller "incomplete" schools, wherein fewer grades are taught (normally first to fifth grades, but sometimes even fewer-see Trnková et al., 2010) and whose students must subsequently commute to a larger 9-year school to complete their elementary education. Moreover, the majority of the latter schools are organized as schools with composite classes, that is, they contain at least one class where students of two or more grades are taught together.

In order to carry out subsequent cartographical visualization, it was necessary to find a way to distinguish between complete elementary schools and incomplete schools, and to indicate the total number of schools in each municipality on a single map. For the purpose of this chapter, we have divided Czechia's municipalities into three categories depending on the highest school level situated therein: municipalities with at least one complete elementary school, at least one incomplete school, or with no elementary school. We have therefore given up on enumerating schools in municipalities, as - especially in more distant time spans-more schools would often be located in the entire municipal territory. We have applied other methods of thematic cartography, accentuating absolute numbers to the detriment of qualitative data, for example, in Kučerová and Kučera (2012) or Kučerová et al. (2015a). In this paper, we will use the outcomes to interpret our data.

\section{Heritage of a Dense School Pattern: The 1960s}

The origins of the dense elementary school network in Czechia date back to the turn of the twentieth century. In 1869, the compulsory education system was constituted according to the Reichsvolksschulgesetz school act in the Habsburg Empire, which Czechia was a part of. Compulsory school began at age six and lasted 8 years for all children. This was the classic period of construction of a network of schools that were distributed as evenly as possible (Váňová, Rýdl, \& Valenta, 1992). The Habsburg Empire's aim was to provide the entire population with uniform elementary schooling for its own needs. Accordingly, most elementary schools, with the exception of ecclesiastical and some private schools, came under state (municipal) authority. Elementary schools, referred to as common schools, were internally structured into starting schools of six grades, with a relatively even spatial distribution, and burgher schools, more frequently found in regional centers. The distance between starting schools ought to have been delimited by a circle with a radius of $4 \mathrm{~km}$ or by $1 \mathrm{~h}$ walking distance (Ván̆ová et al., 1992). Schoolchildren went to the school that was closest to their home. With 


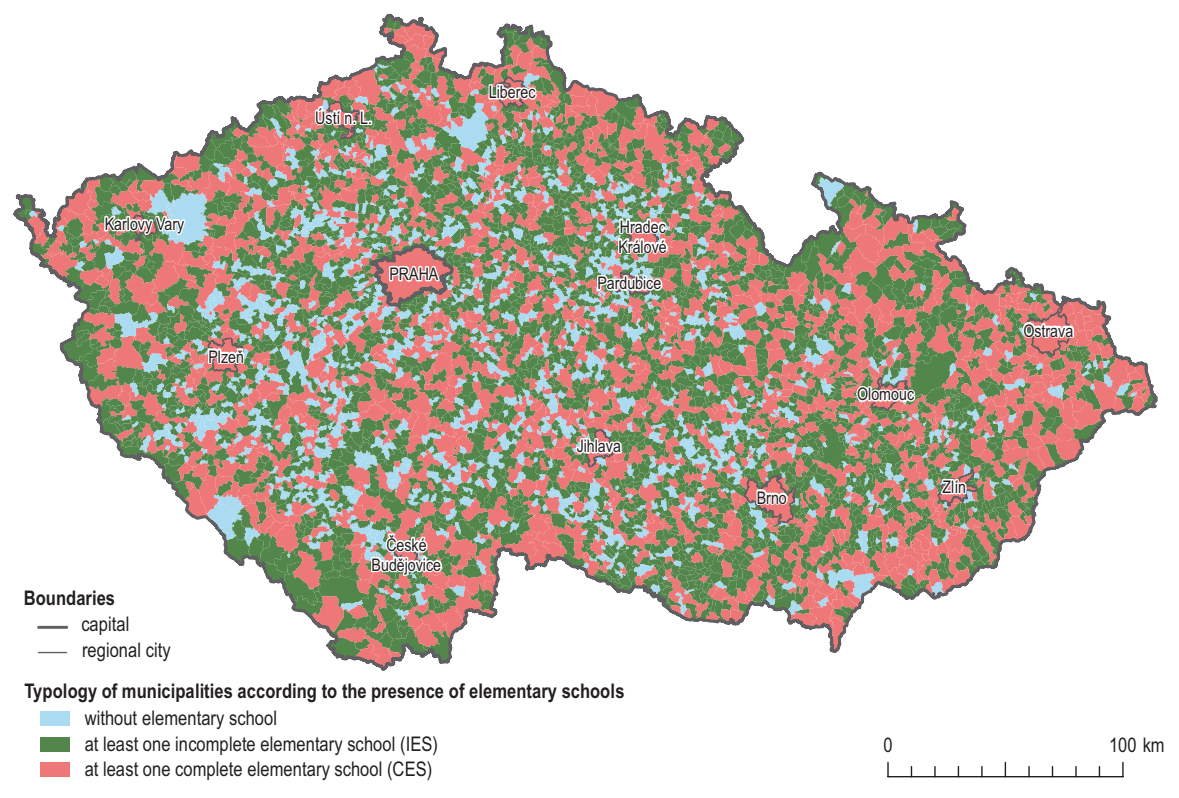

Fig. 7.1 Elementary schools in Czech municipalities in 1961. Source: Petr Meyer. Data from Kučerová, 2012

regard to Czechia's population development - the reverberating demographic revolution (Srb, 2004) - the number of schools showed an upward and then gradually stagnating tendency until World War II (Šimáně, 2010).

The Communist party seized power in Czechia in 1948, incorporating the country into the so-called Eastern Bloc, which lived under communist rule with a centrally planned economy. In the 1950s, the party nationalized the entire schooling system and placed its management and curricula under central supervision (Jelínková \& Smolka, 1989), in compliance with the educational principle of economic nationalism. In 1960, the government radically transformed the school system by adopting the School Act No. 186/1960 Coll., which introduced nine-grade elementary schools (herewith called "schools") consisting of five grades at the first level and four grades at the second level. Mostly rural municipalities with a small number of children in their school's catchment area were still allowed to run schools constituted only of by first-level grades (incomplete school) (Trnková et al., 2010). Such small schools, which symbolized "uneven educational conditions for socialistic state citizens," were gradually abolished from the early 1960s onwards (Kořínek, 1975, p. 216). In 1961, the country had approximately 8000 schools—almost one school per municipality (Kučerová \& Kučera, 2012). Although the network of schools was dense and their spatial distribution relatively even, some areas showed a lower density of schools. This was in particular true for upland regions lying along the state border, which suffered from insufficient resettlement after World War II (Kučera \& Kučerová, 2012) (see Fig. 7.1). 
Settlement and educational policies greatly influenced the development of the school network in rural areas in the 1960s and 1970s. The Communist regime was keen to centralize state administration and remove local public administration by developing the concept of a so-called system of central settlement units, whose goal was to manage settlement network development and to unify all citizens' access to public infrastructure. The policymakers' main tool was the forced concentration of the population in fully equipped settlements, instead of providing widespread public services. Every settlement unit was classified as either "forward-looking" (e.g., these "worth to be maintained," equal to central) or "not-forward-looking" (other, e.g., might be abandoned). Only central settlements could keep their civic amenities and were supported in their urban development and in economic investments (e.g., building up industrial plants) (Musil, 2002). In other settlements, service sector facilities were either closed down or restricted to basic services. Moreover, it was desirable to let such settlements perish due to migration or demographic decline (Hampl \& Müller, 1998). Other European socialist states employed the same method of regional planning (see Bajerski, 2015; Kovács, 2012; see also Chap. 6 by Gyuris in this volume).

These policies had a significant influence on the rural school network as well. A decline in the number schoolchildren reduced the number of rural schools, and most elementary schooling was concentrated in complete schools situated in central municipalities. In certain respects this was justified, as school buildings in peripheral and border regions were in poor condition and often failed to conform to norms of hygiene (Slouka, 1967). Small schools were allowed to carry on only in places where transport, student numbers, or other circumstances preserved the local school from closure. Such reasons included, for instance, bad roads in many regions in the 1960 s and the fact that many rural settlements were off bus line routes. Later improvements in public transport service led to massive school closures (Kučerová et al., 2011).

\section{Massive Centralization: The 1970s and 1980s}

The communist regime's efforts to centralize management and decision-making had an impact on, among other things, increasing placement of children in schools strictly depending on catchment districts, leaving their parents with no free choice. Free schooling choice in disregard of the assigned catchment area was illegal (cf. Maroy \& van Zanten, 2009). Although catchment district policies had existed since the beginning of compulsory education and were simultaneously applied by Western European democracies (Åberg-Bengtsson, 2009; Echols, McPherson, \& Williams, 1990), in Czechia's small rural settlements these policies encouraged animosity towards central municipalities (Perlín \& Šimčíková, 2008). Whenever a school was closed down, its students were transferred to another school by public notice, most often to one situated in the nearest central municipality, which was therefore not faced with a lack of students (Kučerová \& Kučera, 2012). 
The blanket closure of incomplete schools and the construction of complete ones was markedly influenced by the school reform introduced in the 1970s. Based predominantly on a concept developed by Leonid Zankov in the Soviet Union in the 1950s, this reform further elaborated Vygotsky's and Cole's theory of proximal zones (1978). It emphasized children's intellectual development, to the detriment of their social and emotional development. The reform had two key aspects: First, it stressed the necessity of using elements of abstract thinking, even in the first stage of elementary school. Second, according to the principle of effectiveness, it modified the distribution of curricula over individual elementary school grades and accelerated the learning pace. The curricula's volume remained unchanged, but compulsory school attendance was reduced by 1-8 years. Unlike simultaneous reform in states of the former Western block, Czech educational policy forbade any discussion of the disadvantages of these modern ideas or attempts to halt the reforming efforts (Dvořák et al., 2015a). The reform changes were nowhere more perceptible than in primary-level teaching. Initial experience indicated that elementary-level teaching was more demanding in terms of both content and organization and hard to sustain in the smallest schools (Spilková, 1997).

Thus, central schools in key settlements were internalized as a social norm in contrast to small mixed-age schools, similarly to other socialist countries (see Barakat, 2015; Fickermann, Weishaupt, \& Zedler, 1998; Kovács, 2012). This educational policy and the above-mentioned settlement policies of the 1960s and 1970s forced nearly half of Czechia's schools to close down; most of these were rural schools (Kučerová \& Kučera, 2012). One-class and two-class composite schools saw a decline from 4800 in 1960 to 1200 in 1980 (see Fig. 7.2).

Transformations in the spatial distribution of schools are also significant. Figure 7.3 shows the situation after the first stage of school closures in 1976; Fig. 7.4 shows the situation in 1990, after the political turn. The government first abolished schools in border and peripheral regions, generally in the western part of the country, where the population was distributed in a fragmented manner and where school closures were justified due to a lack of students or economic costs. The eastern part of Czechia, which had more populated rural settlements (of over 1000 inhabitants), was only affected by school closures during the 1970s, as a direct consequence of the policy changes discussed above (Kučerová \& Kučera, 2012).

In the 1980s, the main factor conducive to the construction of large schools in bigger rural municipalities was a significant fluctuation in the increased number of schoolchildren. These were children born in the early 1970s, during a period of rising birth rates. The increase was caused by a large, postwar cohort of mothers entering the reproductive age and was combined with short-term, propopulation policies (Srb, 2004). The school-aged population grew rapidly, which led to an imbalance in the population structure and temporary discrepancies between the numbers of children attending compulsory school and school capacity. Teaching was often divided into shifts in a limited number of classrooms and the highest grades were prematurely transferred from small schools to the nearest big schools (Trnková et al., 2010). 
$\square$ one-class $\square$ two-class $\square$ three-class $\square$ four-class $\mathbf{a}$ five-class

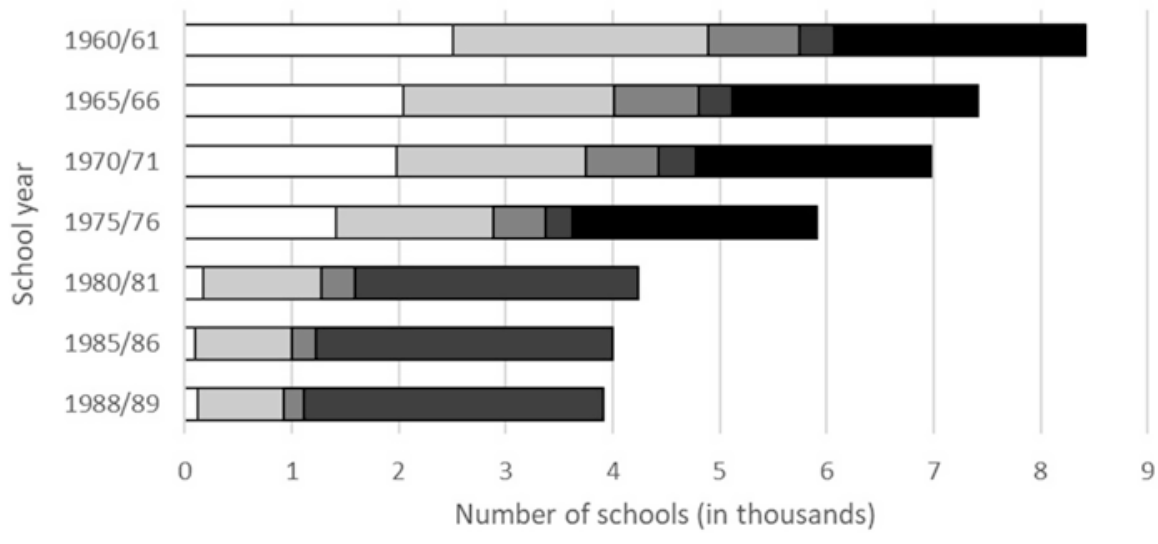

Fig. 7.2 Structure of elementary schools in Czechia according to first-stage organization (ISCED 1) from the 1960s through the 1980s (selected years). Source: Design by author, following Jelínková and Smolka, 1989. Note: Five-class (from the school year 1960/1961 to 1979/1980) and four-class schools (from the school year 1980/1981) are complete schools where each grade has a class of its own. Since the school year 1980/1981, the first stage has been composed of only four grades

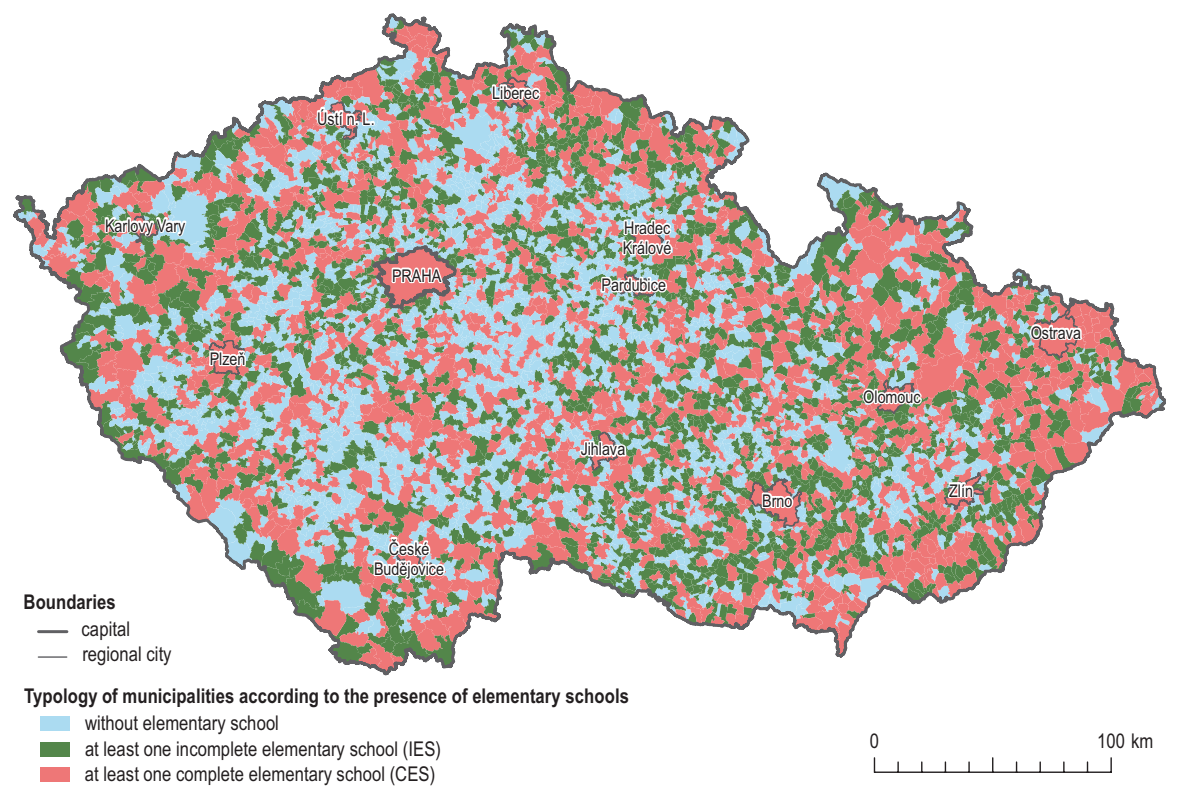

Fig. 7.3 Elementary schools in Czech municipalities, 1976. Source: Petr Meyer. Data from Kučerová, 2012 


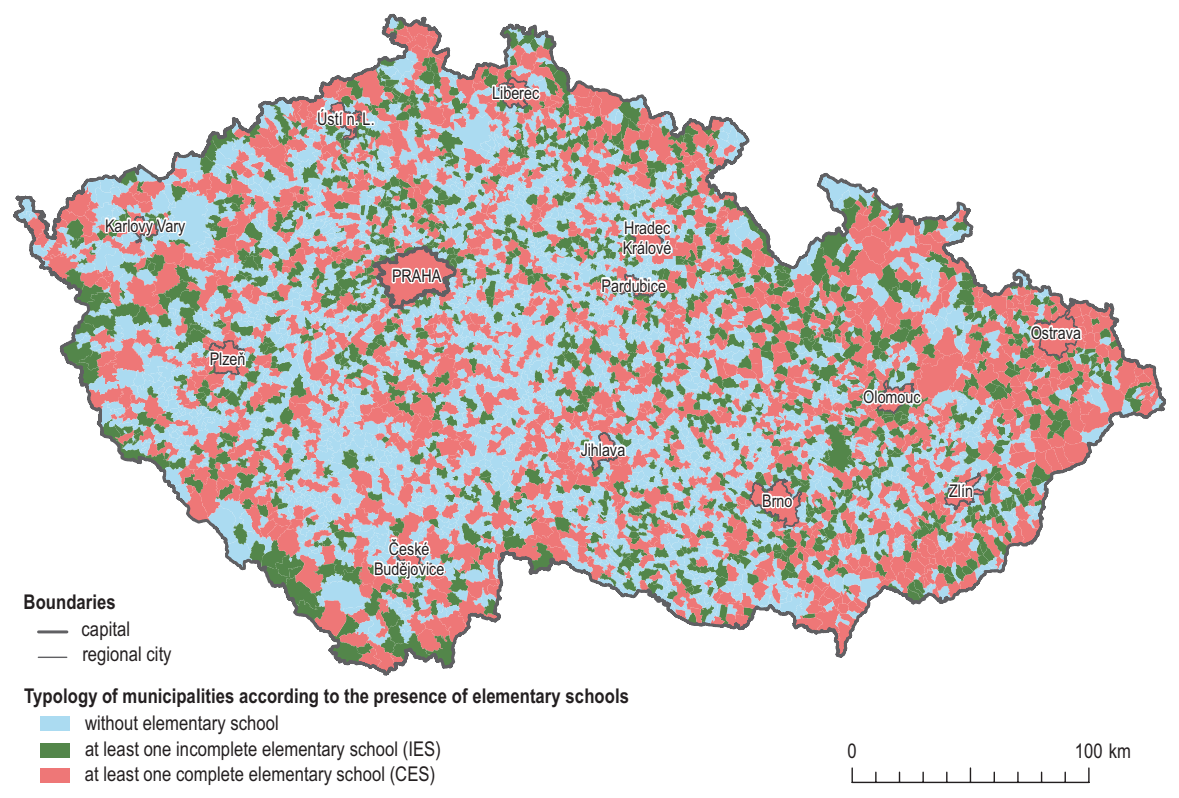

Fig. 7.4 Elementary schools in Czech municipalities, 1990. Source: Petr Meyer. Data from Kučerová, 2012

\section{Transformation of Society: From the 1990s Until Today}

Significant qualitative change in Czech education began only with the fall of the Iron Curtain and the onset of the democratic regime of 1989. The transformation of Czech society included a comprehensive transformation of its educational systemits curricula, didactics, school management, and spatial planning (Dvořák, Starý, \& Urbánek, 2015b; Janík, 2016) have been a part of two forms of transformation. Hampl (1999) refers to the first as a posttotalitarian transformation and to the second as a global societal transition from modern to postmodern society.

The effect of posttotalitarian transformation manifested itself in the transformation of the organization of public administration. The year 1990 saw more than 4000 municipalities return to self-government, while approximately 2000 others disintegrated from their central settlement units (Hampl \& Müller, 1998). The decentralization of political and economic governance passed more autonomy and responsibility on to schools and their operators. The new public administration legislation made municipalities responsible for providing children with schooling (Act No. 128/2000, Coll., on Municipalities). It now thus falls to the local administration to decide whether or not a municipality can run a school. If it cannot, it may make an arrangement with another municipality's school to admit its children (Perlín \& Šimčíková, 2008). Some municipalities decided to restore their local schools that had previously been shut down. Beside the establishment of new private or nonstate schools, this is one reason why roughly 200 new schools emerged in the 1990-1996 
period. Most of these institutions were rural schools with composite classes (Trnková et al., 2010).

The educational system's decentralization is also connected with the transformation of elementary school funding, which is based on two principal sources: the Ministry of Education, which funds schools through a lump-sum per student (to cover teacher salaries and key school equipment), and municipality budgets, which fund school operation and related investment (especially school buildings). A norm regarding the minimum average number of students per class (13) remained incorporated in the School Act until 2009. Unless it achieved the required number, every municipality had to guarantee that the missing costs of teacher salaries and school equipment would be paid from its own budget (Trnková, 2009). Since Czechia's accession to the European Union in 2004, the regional governments have also laid emphasis on acquiring irregular financial resources for school budgets through European cohesion policy funds (e.g., as a part of projects for renovation of buildings or modernization of technological equipment).

In spite of the fact that self-governing municipalities are the dominant operator of Czechia's elementary schools (95\% of schools), more than 100 church and private schools have been established since the 1990s (Kučerová, 2012). At present, we can observe a partial trend of founding other alternative forms of schooling ensured by, for example, parental associations (cf. Hána, 2017; Kraftl, 2012). Further processes related to system decentralization that have been developing in Western European countries since the 1980s (see e.g., Dvořák \& Straková, 2016; Echols et al., 1990; Holloway \& Pimlott-Wilson, 2012) have clearly differentiated forms and types of institutions providing education. They have increased their specialization, but also intensified the competition between them. Schools now participate in the curriculum development process, and student admission is based on the principle of free choice. In the 1990s, the government abandoned its policy of compulsory placement of schoolchildren in their district schools. The School Act No. 561/2004, Coll. leaves parents free to choose where their children will go to school. Nevertheless, some elements of the preceding school district policy have persisted. Municipalities are still obliged to delineate school districts by means of a binding regulation and give preference to local students rather than applicants from other districts (cf. Nekorjak, Souralová, \& Vomastková, 2011).

Although the number of schools has been decreasing slightly since 1996, researchers have observed no distinct changes in their distributions, as illustrated in Fig. 7.5. The possibility of attending a school in one's place of residence is, however, markedly influenced by society-wide trends in population development. On the one hand, student numbers decreased due to the significant birthrate decline after 1989 (Burcin et al., 2010). On the other hand, increased immigration from the large cities to their immediate or wider hinterland at the beginning of the twentyfirst century has put a halt to this decrease, or almost reversed it in some regions. Although peripheral rural areas were struggling with a lack of students, mass suburbanization often doubled the population of the villages in the hinterland of the cities (Ouředníček, Špačková, \& Novák, 2013), rendering the capacity of local schools insufficient (Hulík, Šídlo, \& Tesárková, 2008). 


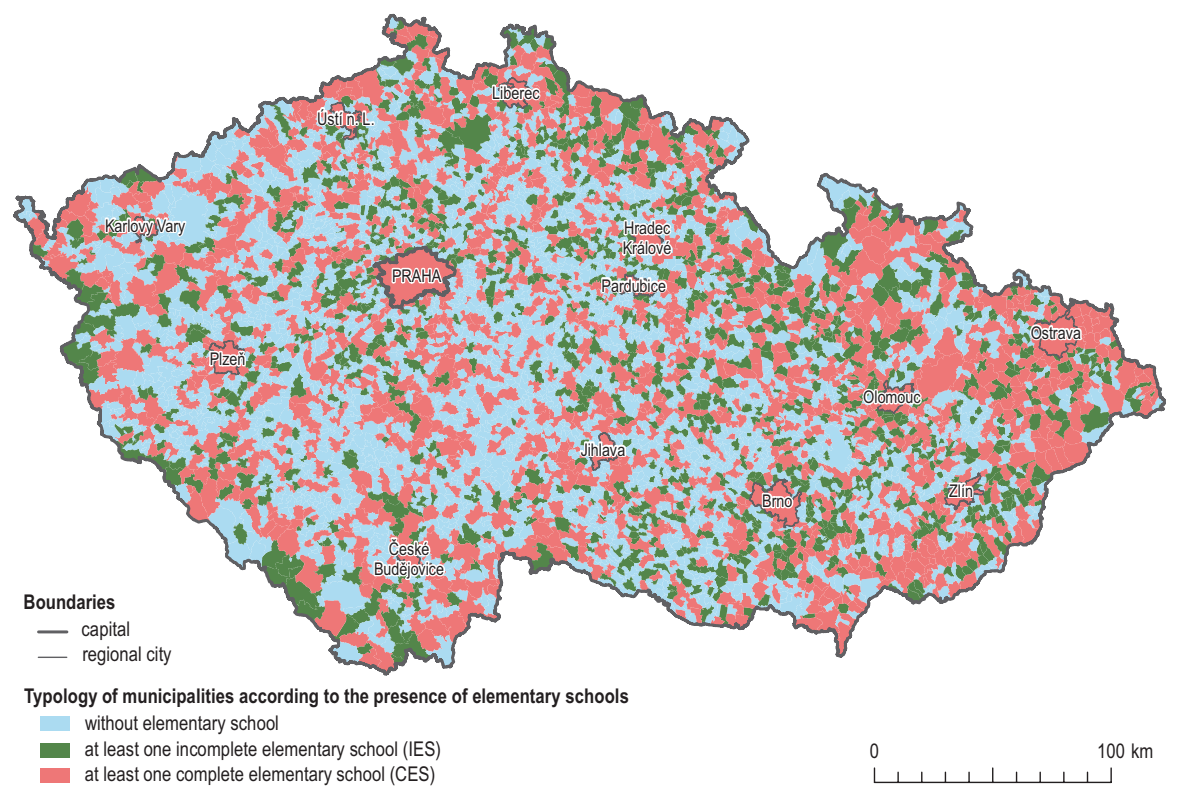

Fig. 7.5 Elementary schools in Czech municipalities, 2004. Source: Petr Meyer. Data from Kučerová, 2012

In 2004, the government adopted a new School Act as part of the school management decentralization process. At its core was a curricular reform shifting part of the responsibility for curricula development to individual schools by means of so-called School Curricular Programs (Dvořák et al., 2015b; Kučerová, Bláha, \& Pavlasová, 2015 b). On the one hand, it increased the potential of place-based curriculum, taking into account the particularities of both schools and students; on the other hand, it cleared the way for a yet stronger market environment and quality-based school differentiation (Dvořák \& Straková, 2016; cf. Geppert, Knapp, Kilian, \& Katsching, 2015). The market behavior of schools is most noticeable in metropolitan areas, not only in terms of parental choice, but also in how schools themselves seek new clients (Dvořák et al., 2015b). Although urban schools have maintained their status of superior institutions in terms of hierarchy and quality (Trnková et al., 2010), small schools - namely those proposing alternative teaching methods-have been appreciated as well (Kučerová et al., 2015b). Czechia's opening up towards the West and globalization tendencies have not merely affected the shape of school curriculum, but also lead to the formation of a new, hierarchically higher social norm of a school that is integrated with international structures (e.g., through interschool cooperation) and positively evaluated in national comparative tests, such as PISA or TIMSS (Dvořák \& Straková, 2016). 


\section{Conclusion}

It is quite challenging to embrace, on a limited number of pages and in a complex manner, the intricate, long-term development of an educational system that often displays contradictory tendencies. We have therefore selected only the most crucial processes provable by primary data or bibliographic sources.

To conclude, the development of Czech elementary schools over the observed period can be divided into five key stages: (1) an increase in school numbers in parallel with the construction of a system of accessible local education until World War II; (2) a decrease of redundant schools in areas with a population decline during the 1960s; (3) an extreme nation-wide decrease in rural schools due to settlement system regulation and educational centralization policies in the 1960s and 1970s; (4) a revitalization of the school network associated with the renewal of local, democratic self-governance in the early 1990s; (5) a continuing slight decrease in school numbers and significant spatial differentiation in education provision due to demographic and migration changes, decentralization, and liberalization of the educational market from the 1990s to today.

As suggested by this chronological listing, the development of the educational system involves mutual relationships among the four dimensions of the provision and realization of education mentioned in this chapter's introduction (changes in educational conditions and demand; view of the role of education; transformations of pedagogical conceptions; educational and regional policies). Various policy combinations (e.g., the system of central settlement units), educational principles (e.g., Vygotsky \& Cole's, 1978 theory), and notions about education's function (e.g., van de Werfhorst's, 2014 tasks of education) are materialized by those who have the power to implement them. It is thereby that a structure is formed in correspondence to Giddens's conception (1984) of the educational system. Various types of schools, along with their relationships to their environs, are deployed spatially. Actors are limited, as they must act within the confines of this structure. Some of them help maintain the structure, whereas others modify or disrupt it.

In the period of the unfree communist regime, Czechia's educational system functioned within a centralized and authoritatively controlled structure whose makers were striving for unification. The spatial population distribution was dictated by a policy defining which settlements should prosper and where local services (schools) should close down. Students' distribution across schools was determined by the catchment district system. The structure thus forestalled any free choice, which could only be exercised secretly. This structure, too, was differentiated due to the effect of various factors (Hampl \& Müller, 1998). A complete, nine-grade urban school became the social norm in education. The structure was especially disturbed by the frequent declines of small rural schools, whereby relations in every environment were changing (Kučerová et al., 2015a).

After the renewal of the democratic regime and Czechia's integration into European structures, the country's educational system began to transform into a system of autonomous units participating in the formulation of educational principles and objectives. The distribution of inhabitants in space and that of school- 
children across schools followed the rules of free market and free choice. Freedom, however, imposed limits on the scope of schools' activities, forcing them into commercialization. The national norm is now a school that ideally enables every individual to succeed in subsequent levels of education (Dvořák et al., 2015b). Actors have a great possibility to create and recreate the structure, although both physical and mental obstacles exist (e.g., the impossibility of choosing a local school that was closed in the past). Choice thus becomes a limitation as well, as not all individuals and schools can succeed in the competition (e.g., the chosen school cannot admit a student due to insufficient capacity). The varying success rates therefore polarize the system.

Acknowledgements The paper is supported by the research project of the Grant Agency of the Charles University No. SVV UK 260425. The authors thank it for the support given.

\section{References}

Åberg-Bengtsson, L. (2009). The smaller the better? A review of research on small rural schools in Sweden. International Journal of Educational Research, 48, 100-108. https://doi. org/10.1016/j.ijer.2009.02.007

Altrichter, H., Heinrich, M., \& Soukup-Altrichter, K. (2014). School decentralization as a process of differentiation, hierarchization and selection. Journal of Education Policy, 29, 675-699. https://doi.org/10.1080/02680939.2013.873954

Bajerski, A. (2015). Erosion of the school catchment system as local policy: The case of Poznan, Poland. KEDI Journal of Education Policy, 12, 41-60. Retrieved from http://eng.kedi.re.kr/ khome/eng/kjep/pubView.do

Barakat, B. (2015). A "recipe for depopulation"? School closures and local population decline in Saxony. Population, Space and Place, 21, 735-753. https://doi.org/10.1002/psp.1853

Bell, A., \& Sigsworth, A. (1987). The small rural primary school: A matter of quality. London: Falmer.

Berg, G. (2007). From structural dilemmas to institutional imperatives: A descriptive theory of the school as an institution and of school organizations. Journal of Curriculum Studies, 39, 577-596. https://doi.org/10.1080/00220270600880994

Bertrand, Y. (1998). Théories contemporaines de l'éducation [Contemporary theories of education] (4th ed.). Lyon, France: Chronique Sociale.

Burcin, B., Fialová, L., Rychtaříková, J., Bartoňová, D., Kalibová, K., Kocourková, J., \& Kučera, T. (2010). Demografická situace České republiky: Proměny a kontexty 1993-2008 [Demographic situation in the Czech Republic. Changes and contexts in 1993-2008]. Prague, Czech Republic: Slon.

Cloke, P., \& Goodwin, M. (1992). Conceptualizing countryside change: From post-fordism to rural structured coherence. Transactions of the Institute of British Geographers, 17, 321-336. https://doi.org/10.2307/622883

Corbett, M. (2007). Learning to leave: The irony of schooling in a coastal community. Black Point, Canada: Fernwood.

Cucchiara, M. B., \& Horvat, E. M. (2014). Choosing selves: The salience of parental identity in the school choice proces. Journal of Education Policy, 29, 486-509. https://doi.org/10.1080/0 2680939.2013.849760

Dewey, J. (1966). Democracy and education: An introduction to the philosophy of education. New York: The Free Press. 
Dostál, P. F., \& Markusse, J. D. (1989). Rural settlement networks and elementary service provision: Two scenarios for the matching of demand and supply. In G. Clark, P. Huigen, \& F. Thissen (Eds.), Planning and the future of the countryside: Great Britain and the Netherlands (pp. 62-78). Nederlandse Geografische Studies: Vol. 92. Amsterdam, the Netherlands: Koninklijk Nederlands Aardrijkskundig Genootschap.

Dvořák, D., Starý, K., \& Urbánek, P. (2015a). Malá škola po pěti letech: proměny školy v době reformy [A small school revisited: School change in the time of reform]. Pedagogická Orientace, 25, 9-31. https://doi.org/10.5817/PedOr2015-1-9

Dvořák, D., Starý, K., \& Urbánek, P. (2015b). Škola v globální době: Proměny pěti českých základních škol [School in the global age: Transformation of five Czech elementary schools]. Prague, Czech Republic: Karolinum.

Dvořák, D., \& Straková, J. (2016). Konkurence mezi školami a výsledky žáků v České republice: Pohled zblízka na šetření PISA 2012 [School competition and pupil achievement in the Czech Republic: A close look at the PISA 2012 study]. Pedagogika, 66, 206-229. https://doi. org/10.14712/23362189.2015.740

Echols, F., McPherson, A., \& Williams, J. D. (1990). Parental choice in Scotland. Journal of Education Policy, 5, 207-222. https://doi.org/10.1080/0268093900050301

Fickermann, D., Weishaupt, H., \& Zedler, P. (1998). Kleine Grundschulen in Deutschland: Rückblick und Ausblick [Small elementary schools in Germany: Hindsight and outlook]. In D. Fickermann, H. Weishaupt, \& P. Zedler (Eds.), Kleine Grundschulen in Europa: Berichte aus elf europäischen Ländern [Small elementary schools in Europe: Reports from eleven European countries] (pp. 7-34). Weinheim, Germany: Deutscher Studien Verlag.

Geppert, C., Knapp, M., Kilian, M., \& Katsching, T. (2015). Volba školy pod tlakem reformních snah [School choice under the pressure of reform efforts]. Studia Paedagogica, 20, 10-28. https://doi.org/10.5817/SP2015-1-2

Giddens, A. (1984). The constitution of society: Outline of the theory of structuration. Cambridge, UK: Polity.

Green, B., \& Letts, W. (2007). Space, equity, and rural education: A "trialectical" account. In K. N. Gulson \& C. Symes (Eds.), Spatial theories of education: Policy and geography matters (pp. 57-76). Routledge research in education: Vol. 9. New York: Routledge.

Halfacree, K. H. (1993). Locality and social representation: Space, discourse and alternative definitions of the rural. Journal of Rural Studies, 9, 23-37. https://doi. org/10.1016/0743-0167(93)90003-3

Halsey, A. H., Lauder, H., Brown, P., \& Wells, A. S. (Eds.). (1997). Education: Culture, economy, and society. Oxford, UK: Oxford University Press.

Hampl, M. (Ed.). (1999). Geography of societal transformation in the Czech Republic. Prague, Czech Republic: Department of Social Geography and Regional Development, Charles University.

Hampl, M. (2000). Reality, society and geographical/environmental organization: Searching for an integrated order. Prague, Czech Republic: Department of Social Geography and Regional Development, Charles University.

Hampl, M., \& Müller, J. (1998). Jsou obce v České republice př́liš malé? [Are municipalities in the Czech Republic too small?]. Geografie, 103, 1-12. Retrieved from http:// geography.cz/sbornik/wp-content/uploads/downloads/2014/03/1998_103_1_Hampl_Muller_ Jsouobcevceskerepubliceprilismale.pdf

Hána, D. (2017). Systémy domácího vzdělávání v Evropě [Home education systems in Europe]. Informace ČGS, 36, 20-30. Retrieved from https://geography.cz/informace-cgs/ informace-cgs-20171-160/

Holloway, S. L., \& Pimlott-Wilson, H. (2012). Neoliberalism, policy localisation and idealised subjects: A case study on educational restructuring in England. Transactions of the Institute of British Geographers, 37, 639-654. https://doi.org/10.1111/j.1475-5661.2011.00498.x 
Hruška, V. (2014). Proměny přístupů ke konceptualizaci venkovského prostoru v rurálních studiích [Changing approaches to the conceptualization of rural space in rural studies]. Sociologický Časopis, 50, 581-601. https://doi.org/10.13060/00380288.2014.50.4.109

Hulík, V., Šídlo, L., \& Tesárková, K. (2008). Míra účasti dětí na předškolním vzdělávání a faktory ovlivňující její regionální diferenciaci [Children's participation in preschool education and factors influencing its regional distribution]. Studia Paedagogica, 13, 13-34. Retrieved from http://www.phil.muni.cz/journals/index.php/studia-paedagogica/article/view/193/308

Janík, T. (2016). Aktuelle Entwicklungen im Bildungsbereich in der Tschechischen Republik: Curriculum-Unterricht-Lehrerbildung [Recent developments in education in the Czech Republic: Curriculum-Teaching-Teachers' training]. Münster, Germany: Waxmann.

Jelínková, V., \& Smolka, R. (1989). Základní školství v ČSSR a nékteré trendy jeho vývoje od roku 1921 [Elementary education in the CSSR and particular trends in its development from 1921]. Prague, Czech Republic: Ústav školských informací.

Jennings, J. L. (2010). School choice or schools' choice? Managing in an era of accountability. Sociology of Education, 83, 227-247. https://doi.org/10.1177/0038040710375688

Kořínek, M. (1975). Perspektivy počátečního stupně základní školy [Perspectives on the first stage of elementary school]. Prague, Czech Republic: SPN.

Kovács, K. (2012). Rescuing a small village school in the context of rural change in Hungary. Journal of Rural Studies, 28, 108-117. https://doi.org/10.1016/j.jrurstud.2012.01.020

Kraftl, P. (2012). Towards geographies of "alternative" education: A case study of UK home schooling families. Transactions of the Institute of British Geographers, 38, 436-450. https:// doi.org/10.1111/j.1475-5661.2012.00536.x

Kramer, C. (1993). Die Entwicklung des Standortnetzes von Grundschulen im ländlichen Raum: Vorarlberg und Baden-Württemberg im Vergleich [The development of the network of primary schools in rural areas: A comparison of Vorarlberg and Baden-Württemberg]. Heidelberger Geographische Arbeiten: Vol. 93. Heidelberg, Germany: Selbstverlag des Geographischen Instituts der Universität Heidelberg.

Kučera, Z. (2007). Sídlo a obec: základní pojmy geografie osídlení a jejich vztah. [Settlement and municipality: Fundamental terms in geography of settlements and their relationship]. Geografie, 112, 84-94. Retrieved from https://geography.cz/sbornik/ starsi-clanky-z-geografie-sborniku-cgs-2007-385/

Kučera, Z., \& Kučerová, S. (2012). Historical geography of persistence, destruction and creation: The case of rural landscape transformations in Czechia's resettled borderland. Historická Geografie, 38, 165-184. Retrieved from http://www.hiu.cas.cz/cs/download/casopisy-elektronicky-na-web/hg-38-1-2012-web.pdf

Kučerová, S. (2012). Proměny územní struktury základního školství v Česku [Changes in the territorial structure of primary education in Czechia]. Prague, Czech Republic: C̆GS.

Kučerová, S., \& Kučera, Z. (2012). Changes in the spatial distribution of elementary schools and their impact on rural communities in Czechia in the second half of the 20th century. Journal of Research in Rural Education, 27(11), 1-17. Retrieved from http://jrre.vmhost.psu.edu/wpcontent/uploads/2014/02/27-11.pdf

Kučerová, S., Mattern, T., Štych, P., \& Kučera, Z. (2011). Změny dostupnosti základních škol v Česku jako faktor znevýhodnění regionů a lokalit [Changes in the accessibility of elementary schools in Czechia as a factor of disadvantage impacting regions and localities]. Geografie, 116, 300-316. Retrieved from http://geography.cz/sbornik/wp-content/uploads/2011/10/g113-5kucerova.pdf

Kučerová, S. R., Bláha, J. D., \& Kučera, Z. (2015a). Transformations of spatial relationships in elementary education: A case study of changes in two Czech rural areas since the second half of the 20th century. Moravian Geographical Reports, 23, 34-44. https://doi.org/10.1515/ mgr-2015-0004

Kučerová, S. R., Bláha, J. D., \& Pavlasová, Z. (2015b). Malé venkovské školy na trhu se základním vzděláváním: Jejich působnost a marketing na př́íkladu Turnovska [Small rural schools in the primary education market: The example of the Turnov region]. Sociologicky Časopis, 51, 607-636. https://doi.org/10.13060/00380288.2015.51.4.209 
Kvalsund, R. (2009). Centralized decentralization or decentralized centralization? A review of newer Norwegian research on schools and their communities. International Journal of Educational Research, 48, 89-99. https://doi.org/10.1016/j.ijer.2009.02.006

Lyson, T. A. (2002). What does a school mean to a community? Assessing the social and economic benefits of schools to rural villages in New York. Journal of Research in Rural Education, 17, 131-137. Retrieved from http://jrre.vmhost.psu.edu/wp-content/uploads/2014/02/17-3_1.pdf

Maroy, C., \& van Zanten, A. (2009). Regulation and competition among schools in six European localities. Sociologie du travail, 51, 67-79. https://doi.org/10.1016/j.soctra.2009.01.005

Marsden, W. E. (1977). Historical geography and the history of education. History of Education, 6, 21-42. https://doi.org/10.1080/0046760770060104

Meusburger, P. (1998). Bildungsgeographie: Wissen und Ausbildung in der räumlichen Dimension [Geography of education: Knowledge and education in the spatial dimension]. Heidelberg, Germany: Spektrum.

Meusburger, P. (2015). Geography of education. In J. D. Wright (Ed.), International encyclopedia of the social \& behavioral sciences: Vol. 7 (2nd ed., pp. 165-171). Oxford, UK: Elsevier.

Musil, J. (2002). Urbanizace českých zemí a socialismus [Urbanization of Czech lands and socialism]. In P. Horská, E. Maur, \& J. Musil (Eds.), Zrod velkoměsta: Urbanizace českých zemí a Evropa (pp. 237-297). Prague, Czech Republic: Paseka.

Nekorjak, M., Souralová, A., \& Vomastková, K. (2011). Uvíznutí v marginalitě: Vzdělávací trh, "romské školy" a reprodukce sociálně prostorových nerovností [Stuck in marginality: The education market, "Roma schools" and the reproduction of social and spatial inequalities]. Sociologický Časopis, 47, 657-680. Retrieved from http://sreview.soc.cas.cz/uploads/ d5584d9fa64d97a2eb797f12e6897e3bbb28a041_Nekorjak\%20soccas2011-4.pdf

Noreisch, K. (2007). Choice as rule, exception and coincidence: Parents' understandings of catchment areas in Berlin. Urban Studies, 44, 1307-1328. https://doi. org $/ 10.1080 / 00420980701302320$

Ouředníček, M., Špačková, P., \& Novák, J. (Eds.). (2013). Sub urbs: krajina, sídla a lidé [Suburbs: Landscape, settlements and people]. Prague, Czech Republic: Academia.

Perlín, R., \& Šimčíková, A. (2008). Criteria of a successful rural municipality. Europa XXI, 17, 29-43. https://doi.org/10.7163/Eu21.2008.17

Ribchester, C., \& Edwards, B. (1999). The centre and the local: Policy and practice in rural education provision. Journal of Rural Studies, 15, 49-63. https://doi.org/10.1016/ S0743-0167(98)00048-5

Šimáně, M. (2010). K problematice zřizování českých menšinových obecných škol na Ústecku v letech 1867-1918 [On the problems of the foundation of the Czech minority elementary schools in Ústí nad Labem and its surroundings during the 1867-1918 period]. E-Pedagogium, IV/2010, 83-92. Retrieved from http://old.pdf.upol.cz/fileadmin/user_upload/PdF/epedagogium/e-pedagogium_2010/e-pedagogium_IV-2010.pdf

Slouka, T. (1967). Problematika prestavby sítě ZD Š v českých krajích [Issue of the reorganization of elementary school network in Czech regions]. Prague, Czech Republic: VÚP.

Smit, R., Hyry-Beihammer, E. K., \& Raggl, A. (2015). Teaching and learning in small, rural schools in four European countries: Introduction and synthesis of mixed-/multi-age approaches. International Journal of Educational Research, 74, 97-103. https://doi.org/10.1016/j. ijer.2015.04.007

Solstad, K. J. (1997). Equity at risk: Planned educational change in Norway: Pitfalls and progress. Oslo, Norway: Scandinavian University Press.

Spilková, V. (1997). Proměny primární školy a vzdělávání učitelů v historicko-srovnávací perspektivě [Transformation of primary school and teachers' training in a historical comparative perspective]. Prague, Czech Republic: Univerzita Karlova v Praze.

Srb, V. (2004). 1000 let obyvatelstva českých zemí [1000 years of inhabitants of Czech lands]. Prague, Czech Republic: Karolinum.

Straková, J., \& Simonová, J. (2015). Výběr základní školy v ČR a faktory, které jej ovlivňují [Primary school choice in the Czech Republic and related factors]. Sociologický Časopis, 51, 587-606. https://doi.org/10.13060/00380288.2015.51.4.208 
Taylor, C. (2007). Geographical information systems (GIS) and school choice: The use of spatial research tools in studying educational policy. In K. N. Gulson \& C. Symes (Eds.), Spatial theories of education: Policy and geography matters (pp. 77-93). Routledge research in education: Vol. 9. New York: Routledge.

Trnková, K. (2009). Rural schools: Wrinkles for mayors? European Countryside, 1, 105-112. https://doi.org/10.2478/v10091/009-0009-1

Trnková, K., Knotová, D., \& Chaloupková, L. (2010). Málotř́idní školy v České republice [Schools with composite classes in the Czech Republic]. Brno, Czech Republic: Paido.

Tyack, D., \& Cuban, L. (1995). Tinkering toward utopia: A century of public school reform. Cambridge, MA: Harvard University Press.

van de Werfhorst, H. G. (2014). Changing societies and four tasks of schooling: Challenges for strongly differentiated educational systems. International Review of Education, 60, 123-144. https://doi.org/10.1007/s11159-014-9410-8

Váňová, R., Rýdl, K., \& Valenta, J. (1992). Výchova a vzdělání v českých dějinách [Upbringing and education in Czech history] (Part 4). Prague, Czech Republic: Karolinum.

Vygotsky, L. S., \& Cole, M. (1978). Mind in society: The development of higher psychological processes. Cambridge, MA: Harvard University Press.

Witten, K., McCreanor, T., Kearns, R., \& Ramasubramanian, L. (2001). The impacts of a school closure on neighbourhood social cohesion: Narratives from Invercargill, New Zealand. Health \& Place, 7, 307-317. https://doi.org/10.1016/S1353-8292(01)00023-5

Zounek, J., Šimáně, M., \& Knotová, D. (2017). Primary school teachers as a tool of secularisation of society in communist Czechoslovakia. History of Education, 46, 480-497. https://doi.org/1 0.1080/0046760X.2016.1276970

Open Access This chapter is licensed under the terms of the Creative Commons Attribution 4.0 International License (http://creativecommons.org/licenses/by/4.0/), which permits use, sharing, adaptation, distribution and reproduction in any medium or format, as long as you give appropriate credit to the original author(s) and the source, provide a link to the Creative Commons license and indicate if changes were made.

The images or other third party material in this chapter are included in the chapter's Creative Commons license, unless indicated otherwise in a credit line to the material. If material is not included in the chapter's Creative Commons license and your intended use is not permitted by statutory regulation or exceeds the permitted use, you will need to obtain permission directly from the copyright holder.

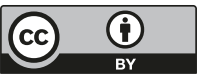

